Review

Author(s): Arthur Tilley and H. Oelsner

Review by: Arthur Tilley and H. Oelsner

Source: The Modern Language Review, Vol. 8, No. 1 (Jan., 1913), pp. 121-130

Published by: Modern Humanities Research Association

Stable URL: http://www.jstor.org/stable/3712675

Accessed: 05-02-2016 15:04 UTC

Your use of the JSTOR archive indicates your acceptance of the Terms \& Conditions of Use, available at http://www.jstor.org/page/ info/about/policies/terms.jsp

JSTOR is a not-for-profit service that helps scholars, researchers, and students discover, use, and build upon a wide range of content in a trusted digital archive. We use information technology and tools to increase productivity and facilitate new forms of scholarship. For more information about JSTOR, please contact support@jstor.org. 
sincerest thanks are due for one of the finest works of Old English scholarship which has been produced in recent years.

NewCAstle-Upon-Trne.

Allen Mawer.

The English Moral Plays. By Elbert N. S. Thompson. (Extract from Transactions of the Connecticut Academy of Arts and Sciences, vol. XIv). New Haven. 1910. 8vo. iv +121 pp.

Students of the drama are already indebted to $\mathrm{Mr}$ Thompson for a valuable account of the relations between the stage and puritanism. The present study deals with a cognate theme. Mr Thompson sets himself to track the various trends of medieval thought and literary expression, which coalesced in the production of that curious dramatic genre, the allegorical morality. It is his primary object to lay more stress than has been laid by his predecessors upon the homiletic factor in the origin of the morality; in fact to suggest the same kind of affiliation between this and the medieval sermon, as has long been established between the miracle-play and the medieval liturgy. It was not, however, quite the same case. The evolution of the miracleplay was a pioneer process, half-unconscious ; the morality did not come into existence at all until the miracle-play had already set up a dramaturgic tradition, and the work of its founders was in adaptation, not discovery. But Mr Thompson's well-informed account of homilaria and exempla and of the use of dialogue by medieval preachers is a useful contribution to the history of the subject. In his later chapters he surveys successively the influence of the themes represented by the Psychomachia and Hamartigenia of Prudentius, of the Creed and Pater-noster plays, of the débats, of the Antichrist legend, of the Dance of Death, and of the Counsel of the Virtues, and indicates the transformation and final disintegration of the morality in contact with the influences of the Reformation and of humanism.

Gerrard's Cross.

E. K. Chambers.

A History of French Literature. By C. H. Conrad Wright. New York: Oxford University Press. 1912. 8vo. xiv +964 pp.

A common fault of general histories of literature is that they are not definitely planned to meet the needs of a particular class of readers. Their authors waver in their aim between the serious student and the reader who is merely interested, and in their efforts to provide for both fail to satisfy either. Mr Wright's volume is no doubt aimed in the first place at the serious student, but unfortunately he has suffered his vision to be distracted by the intrusion of the general 
reader. His own term for this attractive but elusive person is the 'inquisitive foreigner,' and it is doubtless to satisfy this inquisitiveness, which must be much more common in America than in England, that he omits no name that has ever made a figure in literature. A paragraph such as that at the end of the chapter on Rabelais, which sweeps up Des Périers, Bouchet, Du Fail and Béroalde de Verville into a sort of dust-heap, is of no use to the serious student, whatever satisfaction it may give to the 'inquisitive foreigner.' There is a similar dust-heap at the end of the chapter on Racine, but it is when we come to the Nineteenth century that they abound. On p. 681 seven poets are swept up into eleven lines, among them being Mme Desbordes-Valmore who is far more than a 'tearful female sentimentalist,' Barbier and Brizeux At the close of the chapter on Fiction of the latter part of the Nineteenth century, ten novelists, hardly one of whom need have been mentioned at all, are dismissed in little more than a page. On p. 788 a number of minor dramatists are treated with equal summariness. Mr Wright even crowds his pages with dead names. Surely Louise Colet has no place in literature, and who has heard of Mme Blanchecotte? Occasionally, as on p. 675 , names are merely strung together like onions. Finally chapter XvI of Part V is one large dust-heap from which only two men, Renouvier and Brunetière, stand out for particular treatment.

There are other chapters which would be greatly improved by the omission of some names and a fuller treatment and better grouping of others. Such is the omnibus-chapter in Part III, which embraces Men of the World, Scholars, Journalists, and Moralists-a comprehensive heading indeed-and from which possibly Ménage and Cotin, and certainly the Mazarinades, Loret, and Cortinelli might have been omitted, so as to allow fuller treatment of La Bruyère and Saint-Simon. Such, too, is the chapter on miscellaneous dramatic forms in Part IV. Here, while the eight immediate successors of Molière might all have been left out, with the possible exception of Baron, a much more illuminating account might have been given of the interesting group, consisting of Dancourt, Dufresny ${ }^{1}$, Regnard, and Lesage, which produced comedies during the transitional period between Les Caractères (1688) and Les lettres persanes (1721). Especially some notice should have been taken of the influence which La Bruyère had on them all. Lesage's Turcaret is declared to be 'one of the masterpieces of the century,' but no attempt is made to account for this pre-eminence. There is little fault to find with the treatment of Marivaux, save for the paragraph in which he is coupled (inevitably) with Watteau, for the only essential point of resemblance between the dramatist and the great painter is that in their purity of mind they stand apart from their age. The account of the comédie larmoyante and the drame bourgeois is satisfactory, but 'crude realism' is hardly the term to apply to that ridiculous melodrama, Lillo's George Barnwell, and it is a curious omission to

1 Dancourt and Dufresny lack Christian names, and no date is given for Dufresny. 
speak of Sedaine's le Philosophe sans le savoir as the best example-as it certainly is-of the drame bourgeois without an attempt to characterise it. The three pages given to the Théâtre de la Foire and the comic opera might have been considerably shortened, and more informing than a list of Favart's seven best plays would have been a remark that Les trois sultanes is the one by which he is best known, and the only one, I believe, which has been revived in modern times. The chapter ends with the bare mention of Piron's la Métromanie and Gresset's le Méchant, both of which ought to have found a place earlier in the chapter, between Destouches and Nivelle de la Chaussée. The reader should also have been informed that they were the last comedies of any merit to be written in verse for many a long year. Le Méchant, moreover, is very well written and, though it has been overrated, is certainly worth reading. But instead of saying anything about it Mr Wright tells us that Gray admired Gresset's play Sidnei (sic) ${ }^{1}$.

I have made these criticisms, ungracious though they may seen, on a single chapter, not with the object of belittling.Mr Wright's knowledge of his subject, which is exceptionally wide and accurate, but in order to suggest the defects which are inherent in a history of literature written on these ambitious lines. Mr Wright recognises that specialisation in every period is impossible for one man, but it is only the specialist, or at least the man who has thought out a topic for himself, who can be of any real help to the serious student.

But there is a way in which the writer of a general history of literature may help the student, and that is by enabling him to understand the development of literature. The student can get his facts and dates from a dictionary or a bibliography, but a continuous history should help him to co-ordinate his facts, to see his authors in their relations to one another and to their social environment. By dividing French literature merely into centuries $\mathrm{Mr}$ Wright has missed his opportunity. It is no doubt more or less true, as other writers before Mr Wright have pointed out, that 'in France, the end of the century often seems to coincide with a change in the national spirit, and in the literary tendencies.' But literary tendencies change more frequently than once in a century, rather, once in a generation; and a history of literature which is worthy of the name should take account of these shorter periods of change. In such a history Brébeuf (who, by the way, is known by his hymns rather than by his translation of the Pharsalia), Benserade and Segrais, all writers who belong essentially to the period before 1660, would not be sandwiched between La Fontaine and La Fare. As a rule, however, Mr Wright marshals his authors in an orderly sequence, and the chief defect of his arrangement is that it fails to bring out the importance and interest of transitional periods. It is also a mistake to treat the Eighteenth century as a whole, without taking account of the differences between its earlier phase (1721-1750) and that which preceded the Revolution.

1 Gray also says that le Méchant is 'one of the very best Dramas I ever met with' (Gray to Wharton, June 5, 1748). 
Mr Wright's introductory and general chapters are among the best in his book, and his claim that 'the relations have been emphasised of literature and social environment,' is thoroughly justified. The chapters on Humanism (II), the Pléiade and its Theories (VI), the New Philosophy and the New Humanism (VIII) in Part II, the earlier chapters in Part III and Part IV, and the two chapters in Part V on the Trend of Thought (IV and v), which are based on M. Faguet's admirable Politiques et Moralistes du XIX $X^{e}$ siècle, are all excellent. Best perhaps of all is the chapter on the Second Half of the Nineteenth Century (XII), with its well-informed and sagacious handling of SainteBeuve, Taine, and Renan. Another good chapter is that on Philosophy and Descartes in Part III. It is clear that Mr Wright is more interested in the history of thought and social forces than in literary form. For instance, in the interesting chapter on Romanticism he dwells more on its social manifestations than on its literary characteristics, and in the chapter on Diderot and the Encyclopædia the part which treats of Diderot's purely literary work-he says strangely that his chief merit rests to-day on his Salons - is decidedly inferior to that which deals with the Encyclopædia.

Mr Wright's handling of the chief names of French literature is sane and judicious, but it.is neither sympathetic nor illuminating. $\mathrm{He}$ is more ready with criticism than with praise, and he does not succeed in bringing out the qualities in each writer which constitute his real claim to greatness. With regard to Molière, for instance, he does not do justice either to his wonderful range of comic power, or to his mastery of dramatic dialogue, or to the admirable construction of his plays-a merit which is too often overlooked-or to his truth to nature, or to the astonishing boldness and prescience of his social satire. 'It was the tragedy of life amid its comedy that he tried to show in his three great plays,' says Mr Wright. Rather he tried to show the comedy of life amid its tragedy. Or, as M. Lemaître puts it, 'if he happens to be tragic, it is in his own despite and from the nature of things.' Mr Wright notes the difficulty that the foreign reader finds in appreciating Racine, and he seems to share this difficulty himself. $\mathrm{He}$ is short on Bossuet, and he does not do justice to the complex character of Fénelon. Though he realizes the great influence exercised by Chateaubriand, he does not sufficiently point out his marvellous power of literary presentation, and to say that he is 'one of the worst liars and plagiarists in literature' is crude and misleading. Victor Hugo fares worse, for it is only after six pages of more or less adverse criticism that we are told that 'unfavorable criticism must cease when we consider him as an epic writer.'

The well-informed chapter on Realist and Naturalist fiction begins with a good account of the whole movement, followed by a sound appreciation of Flaubert, and a criticism of the brothers de Goncourt, which is severe but not unjust. Then comes Zola who is refreshingly described as 'one of the dullest writers in French literature.' A due tribute is paid to the artistic impassivity of Maupassant and to the 
human pathos of Daudet, while Ferdinand Fabre, a true realist, who is too little read, is rightly commended as 'one of the most noteworthy authors of his generation.' But from this point the chapter, except for a page and more devoted to that curious person, Barbey d'Aurevilly, tails off into a bare list of authors and their works.

With great courage Mr Wright has brought his survey down to the Twentieth century, which he treats in two chapters, entitled respectively, The Tendencies, and The Writers. The latter chapter provides us with a convenient 'Who's Who' of living men of letters. The chapter on The Tendencies, dealing as it does with the Dreyfus case, Pragmatism, Bergson, Modernism, the scientific spirit in history and literary criticism, politics, literature and the drama, offers plenty of scope for controversy. Generally, I should say that Mr Wright's view is far too pessimistic, but I have not nearly sufficient knowledge to criticise it in detail. The attack on fichomanie deserves a passing notice. 'The French doctorate dissertations,' says Mr Wright, 'are becoming burdened with undigested and indigestible material.' There is just an element of truth in this, in so far as these dissertations might often be presented in a more thoroughly digested form. But, though one may recognise a danger, one cannot sufficiently admire the industry, the thoroughness, the acuteness, the intelligent sympathy that modern French students of literature bring to their work. Certainly English literature has much to be grateful for in the work of such men as Feuillerat, Legouis, Angellier, and Huchon.

So far as I have noticed, $\mathrm{Mr}$ Wright's book is commendably free from slips and positive errors. But the letter of Henri IV on Plutarch, from which he quotes on p. 208 , has long been shown to be spurious. De Thou's History was surely never called Thuana, which is the name for his Table-talk. The Saturdays of Mdlle de Scudéry can hardly be said to have rivalled the salon of Mme de Rambouillet, for they did not begin till after the Fronde, when Mme de Rambouillet had practically retired from the field. Certain authors call for a rather fuller treatment, as, for instance, Des Périers, Du Bellay, Massillon, Buffon, and Bernardin de Saint-Pierre, and I should have liked a more appreciative notice of the conversations in the Heptaméron and of the Satire Ménippée. Even in Mr Wright's volume you cannot have everything, and I miss, amid so many books which no one wants to read, those memoirs which everyone reads with pleasure. Where are Mme de Caylus, Mme d'Epinay, Mme de Rémusat, and Marbot? Would any one suspect from the bare mention of the memoirs of Louis Racine, Marmontel, and Mme de Staal-Delaunay, what a fund of anecdote and agreeable instruction they contain?

Finally I must give a word of commendation to the Bibliography. Section I, which gives the general bibliography of the subject, will be found especially useful, for it is comprehensive and accurate and shows judgment as well as learning. Section II gives select bibliographies for each chapter; they are well chosen and are up to date, and I have only one general criticism to make, and that is that some indication 
might have been given as to the relative importance of the authorities. For instance, the student might be told which of the four most recent works on Balzac were the most important for his life, and which for criticism of his writings. Similarly, with regard to Molière. In the bibliography of Part II, chapter II (Growth of Humanism) I note seven works that are out of date and practically useless: and I miss Mr P. S. Allen's great edition of Erasmus' Letters, now in course of publication by the Clarendon Press.

If Mr Wright has come short of complete success, it is because he has attempted an impossible task. It is no longer possible for a single man to write a history of a great literature, such as that of France, that will satisfy the requirements of a serious student. This is not merely because with the growth of knowledge the subject has increased in magnitude, but also because the standard of knowledge has become higher. The real student is no longer content with second-hand information in his teachers. But histories of literature of a less ambitious type are still possible. It is still possible-if you have the gifts of an Andrew Lang-to write a history, instinct with personality, which will at once charm the mature reader and stimulate the young beginner. It is still possible, if you are content to forego all literary laurels, to provide the serious student with a business-like record of facts and authorities. It is even possible to write a history of literature which shall be of service to the student, and not without interest to the mere lover of the subject. But he who attempts this must confine himself to what is significant, he must resolutely discard unimportant names, he must pay close attention to environment and other influences, and he must be content to indicate the merits of great authors rather than attempt any formal criticism of them.

Arthur Tilley.

CAMBRIDGE.

Mr Tilley assures me that, not being a specialist in Old French literature, he cannot undertake to review the medieval section of Mr Wright's book; and I have (however reluctantly) to take his word for it.

Mr Wright, too, assures me, in common with all his readers, that his work does not pretend 'to specialisation in every period-a thing which is impossible for one man now that we are, of necessity, either mediævalists or moderns....The author does not aspire, as some do, to the merit of an absolutely independent judgment on every topic. On the contrary, he considers it the duty of the composer of a synthesis to rely, to a reasonable degree, on those who have spent months or years on individual writers whom he must perforce treat summarily. $\mathrm{He}$ sets himself down unhesitatingly as a "pickpurse of another's wit": the authorities from whom he has readily drawn will, it is hoped, be accounted for in the bibliography.' 
The bibliography is, indeed, drawn up with great care ${ }^{1}$ : the Middle Ages alone fill eight closely-printed pages. With regard to the body of the book, this period occupies 122 pages out of 878 - that is to say, four centuries (roughly) are dealt with in a quarter of the work. I do not quarrel with this arrangement; the proportion is the same as in the great history edited by Petit de Julleville.

After carefully reading these 122 pages, it is clear to me that Mr Wright must be ranked among the 'moderns,' and that he has 'readily drawn' from some at least of the authorities quoted in the bibliography. Fortunately he has had sound advisers, and there are few actual blunders: the names of Professors Grandgent and Weeks (in the Preface) are a guarantee for this. But, save perhaps in the chapter dealing with philosophy, I can discover but few traces of first-hand knowledge.

The genres are dealt with in separate chapters-which is probably the most satisfactory course to adopt in the case of a literature that is largely anonymous. The origins are briefly treated-three times the scanty details are eked out with references to Voretzsch, though it should be added that a few lines are devoted to the theories of M. Bédier. A particularly unimaginative introductory account of the epic $(8 \mathrm{pp}$.) ends with a dry analysis of three of the poems-the Roland, Aliscans and Huon de Bordeaux (5 pp.), heralded by the words: "The French epic may perhaps best be understood by a more detailed study of three of its finest examples.'

Under 'Romance' I find that the tales of Marie de France 'are stories of love among lords and ladies, a love more refined than in the rough passions of the chansons de geste or the violent frenzy of the Tristan legend.' Quite so. But what is the unfortunate beginner to make of the sentence immediately following: "They tell of the married woman who loves a knight and tells her lord that she goes to listen to a nightingale; whereupon the cruel husband snares one of these birds and throws the innocent and bleeding thing at his wife, who then sends it to her lover in token that they must no longer meet.' Take the account of the Tristan poems of Beroul and Thomas. Surely everyone

1 Perhaps it would have been better to confine Section I (General Indications) to works of a general kind covering the whole period; as it is, there are necessarily numerous repetitions in the second section, entitled 'systematic bibliography.' As the list does not aim at completeness, no purpose is served by pointing out omissions. Still, Morf's admirable account of Romance literature should certainly have been included. There is a general tendency to neglect works that would make instant appeal-thus, Ker's Dark A ges would obviously delight many readers for whom Gröber's monumental work in the Grundriss is totally unsuited. Again, there are but few references to English versions of old French texts. We hope one day to publish a composite review of these translations, the number of which has risen in a striking degree during the last fifteen years. Finally, Mr Wright's observations on the books quoted are not always happy. G. Paris' E'squisse is obviously 'a different work from' La litt. française au moyen âge; it would have been more useful to point out that the treatment in the one is chronological, in the other according to genres, so that the two books supplement each otber. Darmesteter's Historical Grammar (which should have been quoted in Hartog's English version) is ' $a$ readable study'; and so on. The titles are included of certain books that have been announced to appear-a useful feature. 
knows that 'the story is one of the strongest examples of passionate and romantic love in literature.' But it is very difficult indeed for the uninitiated to discover and understand without aid the undoubted beauties of these particular poems; and no aid is forthcoming. Later on we are told that 'another form of the same motif [that of Floire et Blanchefleur ${ }^{1}$ is one of the masterpieces of medieval literature, the "chante-fable" Aucassin et Nicolette, of the twelfth century or in the present form perhaps of the thirteenth, in prose interspersed with songs.' Not a word to show why it is a masterpiece. Of the Grail we learn that 'by an accretion of symbolism and idealism it has remained in literature until the days of R. S. Hawker, Tennyson and Wagner.' With all respect for the Cornish poet, we can hardly think that he ought to be brought into this company.

When we come to the lyrics things are not much better. The atmosphere of poems like Belle Yolans en ses chambres seoit recalls to our author the pieces of Thomas Haynes Bayly. The pastourelle is 'perhaps the most attractive form of all.' Perhaps it is; but is it helpful to be told that the knight woos the shepherdess 'in the strain of: "Where are you going, my pretty maid?" We are grateful to $\mathrm{Mr}$ Wright for including the Goliardic poetry, with a mention of John Addington Symonds' beautiful book. Indeed, it is an excellent feature of the entire medieval section that Latin literature is called in wherever it is required.

The chapter on 'history, biography and chronicles' contains matter that obviously belongs elsewhere - say to the section following, on 'fable literature and short stories' (though in that case 'legends' should perhaps be added to the title) ${ }^{2}$. Thus the legends of the Virgin cannot properly be classed either as history or biography or chronicles ${ }^{3}$. $\mathrm{Mr}$ Wright has scarcely caught the spirit of these wonderful little poems: he speaks of 'the rather touching story of the Tombeor Nostre Dame' and the man's 'unseemly tricks'.' The modern parallel in this case is

$1 \mathrm{Mr}$ Wright says that this "has heen called the "Paul and Virginia" of the Middle Ages.' Whoever called it that understood neither of the works. I shall have occasion to quote further parallels, many of which strike me as unhappy. The truth of the matter is that, while it may occasionally be useful to contrast medieval and modern works, very little is gained by comparing them, save in cases of obvious imitation.

2 I have found the following a convenient classification for Old French narrative literature. (1) National Epic. (2) Epic of Antiquity. (3) Arthurian Epic and Celtic Romance. (4) Narrative literature exclusive of the epic: (a) the Rose (and allegorical literature); (b) the Renart (and beast literature); (c) religious legends ; (d) fableaux; (e) other tales and romances. The chronicles in verse and prose are perhaps best treated separately or classed under didactic literature.

3 No one will be satisfied with this arrangement. The British Museum authorities, probably in deference to public opinion, adopted the other extreme, and omitted all these legends from their Catalogue of Romances.

4 Let him read Tobler's account of this 'Kleine Legende, die man noch heute nicht ohne lächelnde Rührung liest, so schlicht und treuherzig erzählt sie ein unbekannter Dichter einem lateinischen Buche nach' (in Spielmannsleben im alten Frankreich, now happily rescued from comparative neglect and reprinted, together with much other valuable matter, in the volume containing the fifth series of Vermischte Beiträge, Leipzig, 1912). It is of interest to note that the same motif has been handled by two modern masters: by Gottfried Keller in his poem Der Narr des Grafen von Zimmern; and by 
Massenet's opera Le Jongleur de Nostre Dame. It is true that the librettist has done his work with some skill, but surely Anatole France deserved precedence. An able critic might have contrasted the exquisite sincerity of the medieval artist with the no less exquisite (and probably largely unconscious) irony of the great modern writer ${ }^{1}$. Garnier's $S$. Thomas duly appears in this chapter. We learn that the author was 'a wandering scholar and contemporary of Chrétien de Troyes [which does not help us much], who tried to give an impartial yet vivid and dramatic narrative of his hero's life and death.' Scarcely an adequate account of a really great work!

Coming to the short stories Mr Wright asks: 'Have the fabliaux any merit at all? The single one of realistic observation, though, let us hope, as much overdone as the realism of the modern naturalistic school.' Surely no 'mediævalist' would ever have written this; and many ' moderns' would hesitate to subscribe to the latter portion of the sentence. Old French literature, like the literature and art of every age and country, has to be studied historically. Auberee is a masterpiece no less than the Celestina, though both may be 'unpleasant.'

When we reach the Drama, we get what may be called the 'boxoffice' point of view. 'The great period of the theatre in France does not come until the later Middle Ages: the fifteenth century is the time of its greatest vogue'; or again 'the fifteenth century is the period of the greatest splendour of the French theatre.' The trouble, of course, is that the really 'great period' comes before the fifteenth century. A play is not necessarily good because it runs into thousands of lines or because it is popular. Though $\mathrm{Mr}$ Wright gives a fair account of the earlier pieces he does not seem to realise the simple beauty of such things as the Adam, or the power and originality of men like Jean Bodel and Adam de la Halle.

A writer dealing with allegory is a pretty safe guide if he is sound on the Rose. Though Mr Wright says many things that are undoubtedly true about this extraordinary work, his account lacks enthusiasm and is not likely to win it any fresh readers. 'In spite of the characteristic mediæval redundancy of treatment, the love poem of Guillaume de Lorris contains many an attractive passage'; in the hands of Jean de Meung 'it became a poem of satire of the ideas of his time and a polemical criticism of important topics then under discussion, with violent satire of the clergy and of women.' Bald statements such as these surely need development; a few happily chosen examples, if

Arnold Böcklin in the painting which depicts an aged hermit playing his fiddle before a rude image of the Virgin Mary, while little angels watch him, clapping their hands and laughing for joy.

1 The Vollınöller-Humperdinck-Reinhardt production of The Miracle has familiarised a large public with the legend which, in its original Old French form, is perhaps the most beautiful of them all; the story deserved mention if only for the reason that two modern poets of distinction have revived the theme : John Davidson (The Ballad of a Nun) and Maeterlinck (Sœur Bétrice). The current number of the Odd Volume contains a rendering (the first in English) of the Old French legend by Mr Mason.

M. L. R. VIII. 
nothing else, would serve to carry conviction. The space that might have been devoted to these is taken up with futile points of contact between the two writers; whereas our critic, who was obviously in a hurry, would have been far better occupied in showing how profoundly they differ.

The fourteenth and fifteenth centuries are tackled (save for the Drama which is treated elsewhere) in 13 pages, of which more are devoted to Christine de Pisan ( $2 \frac{1}{2} \mathrm{pp}$.) than to Villon (2 pp.)-the latter one of the few really great lyric poets France has produced. Charles d'Orleans has to be content with $1 \frac{1}{2}$ pages, but it is some satisfaction to learn that his poems 'are the work of a dilettante of genius'; which is, after all, more than can be said for those of Christine, with all her endearing virtues and undoubted gifts. 'There is historical sentiment' in the Ballade des dames des temps judis (which 'ranks among the most famous and most translated poems of French literature'); if so, it is a great lyric in spite of that circumstance. Mr Wright is on firmer ground when he admires the 'true religious feeling in the poem for his mother to Notre Dame ${ }^{1}$.'

I trust I have not been unjust to this section of Mr Wright's book. I do not see that he has any sympathy with the Middle Ages, or that he understands them. If he has read the works he writes about-and there is no reason why he should not have done so, seeing that the leading examples only are dealt with-he has not carried any very definite impression away with him, and consequently he has not succeeded in making any very definite impression on his readers. These pages are obviously intended for beginners; and beginners, like children, should have only of the very best, by reason of their helplessness. The two books of Gaston Paris and his various essays remain the best introduction to the study of Old French literature.

\section{H. Oelsner.}

OXFORD.

Victor Hugo, His Life and Work. By A. F. Davidson. London: Eveleigh Nash. 1912. 8vo. xiii +351 pp.

Le regretté $M$. Davidson est mort avant d'avoir pu mettre la dernière muin à cette monographie sur V. Hugo. Le manuscrit a été publié par les soins de M. Francis Gribble, qui n'y apporte que les corrections et additions strictement indispensables; elles sont d'ailleurs de peu d'importance.

Les 83 années de la vie de V. Hugo sont divisées ici en 21 périodes, ou tableaux, des diverses circonstances qu'ont traversées l'homme privé, l'homme de lettres et l'homme politique. On le suit pas à pas dans sa destinée; on déménage avec lui d'une résidence à l'autre; on le regarde

1 This 'has been compared with Heine's Wallfahrt nach Kevlaar.' I fail to see that any useful purpose is served by this parallel. 